\title{
Pyrolytic Waste Plastic Oil and Its Diesel Blend: Fuel Characterization
}

\author{
M. Z. H. Khan, M. Sultana, M. R. Al-Mamun, and M. R. Hasan \\ Department of Chemical Engineering, Jessore Science and Technology University, Jessore 7408, Bangladesh
}

Correspondence should be addressed to M. Z. H. Khan; zaved.khan@yahoo.com

Received 24 March 2016; Accepted 5 June 2016

Academic Editor: Mynepalli K. C. Sridhar

Copyright (c) 2016 M. Z. H. Khan et al. This is an open access article distributed under the Creative Commons Attribution License, which permits unrestricted use, distribution, and reproduction in any medium, provided the original work is properly cited.

The authors introduced waste plastic pyrolysis oil (WPPO) as an alternative fuel characterized in detail and compared with conventional diesel. High density polyethylene, HDPE, was pyrolyzed in a self-designed stainless steel laboratory reactor to produce useful fuel products. HDPE waste was completely pyrolyzed at $330-490^{\circ} \mathrm{C}$ for $2-3$ hours to obtain solid residue, liquid fuel oil, and flammable gaseous hydrocarbon products. Comparison of the fuel properties to the petrodiesel fuel standards ASTM D 975 and EN 590 revealed that the synthetic product was within all specifications. Notably, the fuel properties included a kinematic viscosity $\left(40^{\circ} \mathrm{C}\right.$ ) of $1.98 \mathrm{cSt}$, density of $0.75 \mathrm{gm} / \mathrm{cc}$, sulphur content of 0.25 (wt\%), and carbon residue of 0.5 (wt\%), and high calorific value represented significant enhancements over those of conventional petroleum diesel fuel.

\section{Introduction}

Plastics have become an indispensable part in today's world, due to their lightweight, durability, and energy efficiency, coupled with a faster rate of production and design flexibility; these plastics are employed in entire gamut of industrial and domestic areas; hence, plastics have become essential materials and their applications in the industrial field are continually increasing. At the same time, waste plastics have created a very serious environmental challenge because of their huge quantities and their disposal problems. Waste plastic pyrolysis in liquid fuel (gasoline, diesel oil, etc.) or chemical raw materials not only can effectively solve the problem of white pollution, but also can alleviate the energy shortage to a certain extent. Recycling of waste plastics is expected to become the most effective way. Waste plastics' recycling, regenerating, and utilizing have become a hot spot of research at home and abroad and gradually formed a new industry [1-6].

The decomposition of polymeric materials is also relevant and of interest to industries since plastic is used in many of today's commodities [7, 8]. The wide use of polymeric materials or plastics resulted in the accumulations of untraditional wastes not native to the mother earth life cycle [9, 10]. Therefore, wastes of modern materials are accumulated without effective decomposition and recycling routes in the landfills. The increase of petroleum and petrochemical prices opened the ways for industries to invest in decomposition of plastic wastes to petrochemicals [11, 12]. Today, plastic landfills are as valuable as petroleum mines. Models for reaction's kinetics for optimal pyrolysis conditions of plastic waste mixtures have been proposed by researchers. Literature abounds in the recycling of these traditional wastes to petrochemicals [13-15] and many industries are sustained and developed based on decomposition of natural and synthetic polymers $[14,15]$. From a scientific-engineering point of view, nondegradability of plastics is no longer an environmental issue in landfills since the plastics can be recycled. However, run-away plastic wastes are continuing to be a huge hazard on the surface and surface water such as waterways, seas, and oceans, endangering safe life for both animals and humans [15].

The plastics include polystyrene [16, 17], poly (vinyl chloride) $[17,18]$, polypropylene [17-19], PE terephthalate [18], acrylonitrile-butadiene-styrene [18], and PE [16-18]. In some cases, plastics were copyrolyzed with other materials such as waste motor oil [18]. With regard to fast pyrolysis of PE, pyrolysis of LDPE [16], HDPE [20, 21], and various mixtures [17] was reported. In all PE studies, the properties of the resulting bio-oil were not reported, nor were the 


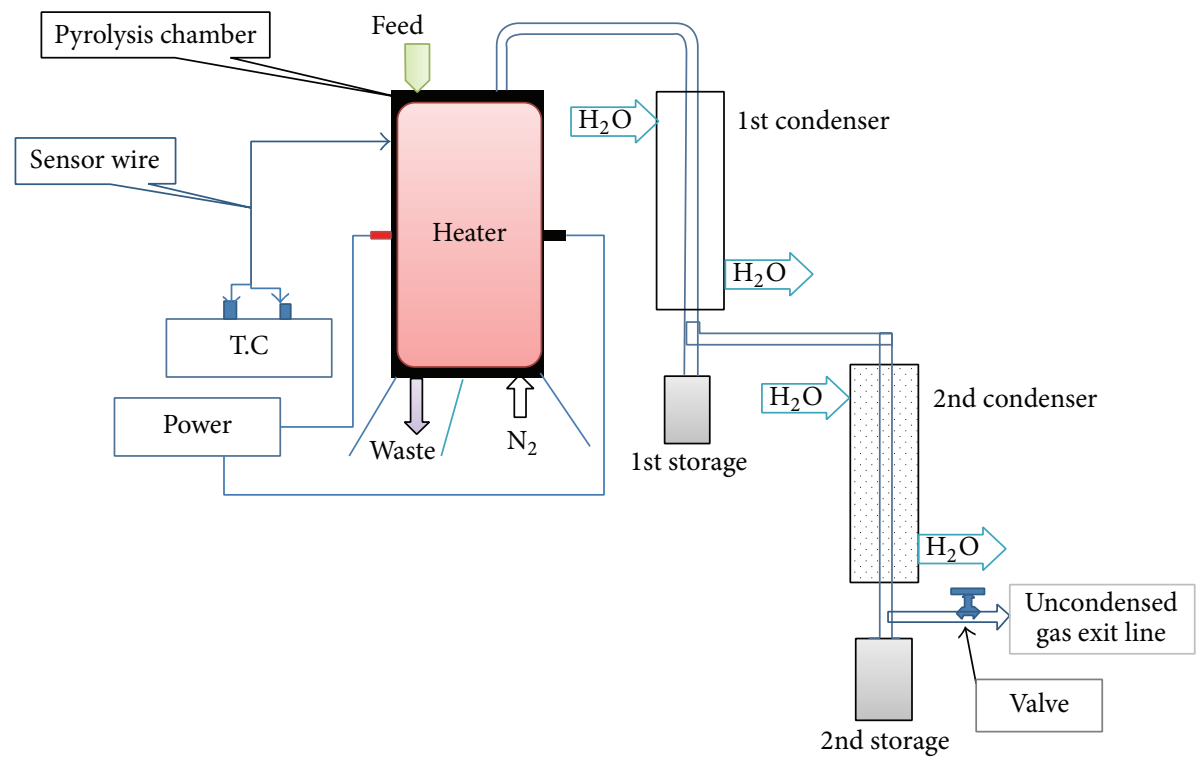

FIGURE 1: Schematic representation of experimental setup.

upgrading to fuel-grade hydrocarbons and subsequent fuel property determination.

The objective of this study was the production, characterization, and evaluation of alternative diesel fuel from pyrolysis of HDPE waste plastics. Comparison of our pyrolyzed oil with conventional petroleum-derived diesel fuel was a further objective, along with a comparison to petrodiesel standards such as ASTM D 975 and EN 590. Blends of waste plastic pyrolysis oil (WPPO) with diesel were prepared and the resultant fuel properties were measured. It is anticipated that these results will further the understanding of the applicability and limitations of HDPE as a feedstock for the production of alternative diesel fuel.

\section{Materials and Methods}

2.1. Materials and Process Description. The plastic used in this study was used waste plastic containers (HDPE) for domestic purposes. Waste plastics were cleaned with detergent and water to remove contained foreign materials such as mud and oil. Washed out waste plastics were dried and cut into small pieces in the range of 0.5 inches to 2 inches by using scissor.

2.2. Experimental Setup. A laboratory scale externally heated fixed bed pyrolysis batch reactor was used for production of oil from plastic. Figure 1 shows the schematic diagram of plastic pyrolysis setup. Basic instruments of the pyrolysis chamber are temperature controller, condenser, temperature sensor, a heating coil, insulator, storage tank, valve, and gas exit line. The effective length and diameter of the stainless steel made reactor are $38 \mathrm{~cm}$ and $15 \mathrm{~cm}$, respectively. The reactor with tire was heated electrically up to $475^{\circ} \mathrm{C}$ with $\mathrm{Ni}$ $\mathrm{Cr}$ wire electric heater. Here it is necessary to mention that the sensor was used through the wall of the stainless steel pyrolysis chamber to measure the temperature. Therefore, the
TABLE 1: Testing methods for fuel properties measurements.

\begin{tabular}{lc}
\hline Properties & Test method \\
\hline Density & IP 131/57 \\
Kinematic viscosity & ASTM D 445 \\
Flash point & ASTM D 93 \\
Fire point & ASTM D 93 \\
Water content & ASTM D 49 \\
Pour point & ASTM D 97 \\
Calorific value & Bomb calorimeter 12/58 \\
Sulphur content & ASTM D 129-00 \\
Carbon residue & ASTM D 189-65 \\
Ash content & ASTM D 48 \\
\hline
\end{tabular}

temperature mention may have appeared small in amount as compared to conventional system. Besides, a nitrogen hole was used in the pyrolysis chamber to provide uniform heating across the cross-section of the reactor chamber and to create inert environment in the pyrolysis chamber.

There was no output at low temperature range and the process was carried out between the temperature ranges of $330^{\circ} \mathrm{C}$ and $490^{\circ} \mathrm{C}$ in the reactor for about two hours and forty minutes. The vapor products of pyrolysis were carried out through two condensers. The condensers were cooled by water and the condensed bio-oil was collected into two collectors. The noncondensed gas was flared to the atmosphere and the char was collected from the reactor after completion of pyrolysis cycle.

2.3. Fuel Properties. All the fuel properties of the oil were tested by the following methods which are summarized in Table 1 . 


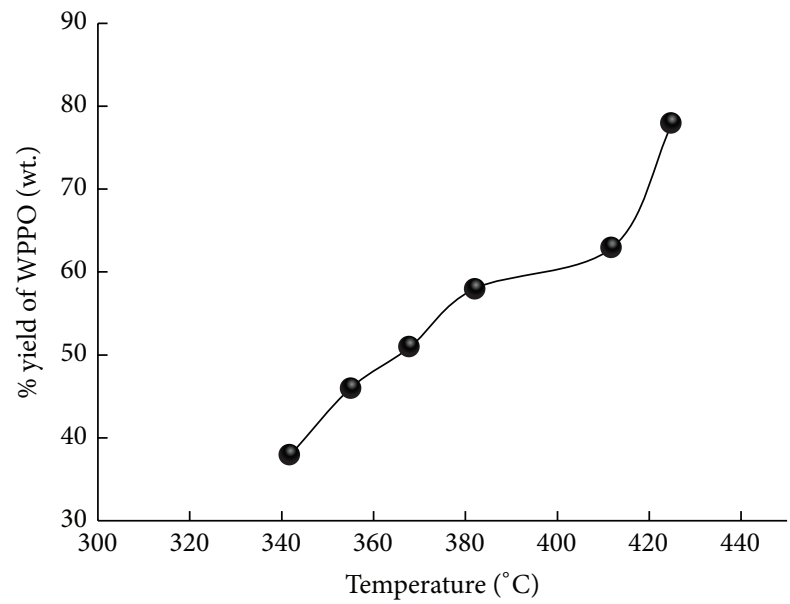

FIGURE 2: Effect of temperature on product yield.

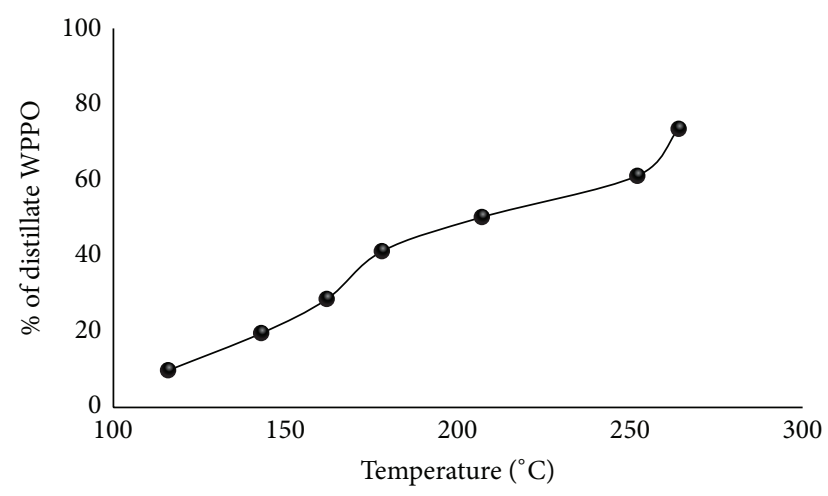

FiguRE 3: Effect of temperature on distillate product yield.

The density measurement is done with accuracy of $\pm 0.0005 \mathrm{~g} / \mathrm{mL}$ and the other parameters such as pour point, flash point, and fire point are measured with $\pm 1^{\circ} \mathrm{C}$ accuracy.

\section{Results and Discussion}

3.1. Effect of Temperature on Product Yield. The products are separated into gas, oil, and char residue by pyrolysis of waste plastic. About $38.5 \%$ of WPPO was obtained at temperature $330^{\circ} \mathrm{C}$ as presented in Figure 2 . The oil percentage increased constantly to $76.0 \%$ at $425^{\circ} \mathrm{C}$. The gases produced through plastic pyrolysis consist principally of hydrogen $\left(\mathrm{H}_{2}\right)$, carbon dioxide $\left(\mathrm{CO}_{2}\right)$, carbon monoxide $(\mathrm{CO})$, methane $\left(\mathrm{CH}_{4}\right)$, ethane $\left(\mathrm{C}_{2} \mathrm{H}_{4}\right)$, and butadiene $\left(\mathrm{C}_{4} \mathrm{H}_{6}\right)$, with trace amounts of propane $\left(\mathrm{CH}_{3} \mathrm{CH}_{2} \mathrm{CH}_{3}\right)$, propene $\left(\mathrm{CH}_{3} \mathrm{CH}=\mathrm{CH}_{2}\right)$, n-butane $\left(\mathrm{CH}_{3}\left(\mathrm{CH}_{2}\right)_{2} \mathrm{CH}_{3}\right)$, and other miscellaneous hydrocarbons.

3.1.1. Effect of Distillation Temperature on Crude WPPO. Distillation is carried out to separate the lighter and heavier fraction of hydrocarbon present in waste plastic pyrolysis oil. The distillation is operated between $116^{\circ} \mathrm{C}$ and $264^{\circ} \mathrm{C} ; 73.5 \%$ of WPPO is distilled out. At the temperature of $116^{\circ} \mathrm{C}$ only about $10.0 \%$ of distilled WPPO was achieved as shown in Figure 3.
TABLE 2: Characteristics of waste plastic pyrolysis oil.

\begin{tabular}{lc}
\hline Properties & WPPO \\
\hline Viscosity at $40^{\circ} \mathrm{C}(\mathrm{cSt})$ & 1.980 \\
Density at $40^{\circ} \mathrm{C}(\mathrm{g} / \mathrm{cc})$ & 0.7477 \\
Carbon residue $(\mathrm{wt} \%)$ & 0.5 \\
Ash content $(\%)$ & 0.036 \\
Sulphur content $(\%$ of wt.) & 0.246 \\
Flash point $\left({ }^{\circ} \mathrm{C}\right)$ & 15 \\
Pour point $\left({ }^{\circ} \mathrm{C}\right)$ & $<-15$ \\
Fire point $\left({ }^{\circ} \mathrm{C}\right)$ & 20 \\
Calorific value $(\mathrm{kcal} / \mathrm{kg})$ & 9829.35 \\
\hline
\end{tabular}

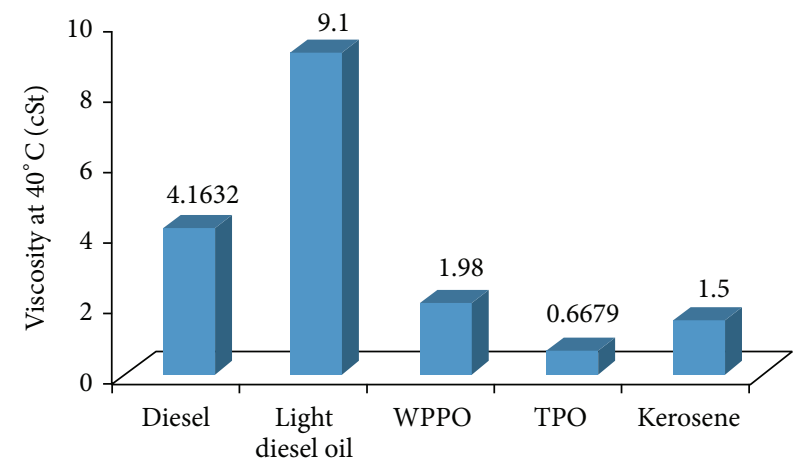

FIGURE 4: Graphical comparison of viscosity different oil. Diesel oil is $100 \%$ distillate oil, whereas light diesel oil is mixture of distillate oil and residual oil.

However, percentage of WPPO increased constantly to $73.5 \%$ at a temperature of $264^{\circ} \mathrm{C}$ from $10 \%$ at the temperature $116^{\circ} \mathrm{C}$.

\subsection{Analysis of Waste Plastic Pyrolysis Oil}

3.2.1. Physiochemical Analysis. The waste plastic has high volatile content $77.03 \%$ by weight which is suitable for pyrolysis conversion of organic solid wastes to liquid product. The characteristics of waste plastic pyrolysis oil obtained at $425^{\circ} \mathrm{C}$ are shown in Table 2.

3.2.2. Viscosity. Viscosity varies with feedstock, pyrolysis conditions, temperature, and other variables. The higher the viscosity, the higher the fuel consumption, engine temperature, and load on the engine. On the other hand, if the viscosity of oil is too high, excessive friction may take place. The viscosity was measured by the IP-50 methodology at a temperature of $40^{\circ} \mathrm{C}$. From Figure 4 it is observed that the viscosity of waste plastic pyrolysis oil obtained at $425^{\circ} \mathrm{C}$ pyrolysis temperature was $1.98 \mathrm{cSt}$ which was comparably higher than kerosene and lower than diesel.

3.2.3. Density. Density is an important property of a fuel oil. If the density of fuel is high; the fuel consumption will be less. On the other hand, the oil with low density will consume more fuel which may cause damage to the engine. Therefore, too low or too high density of fuel oil is not desirable. It is clear 


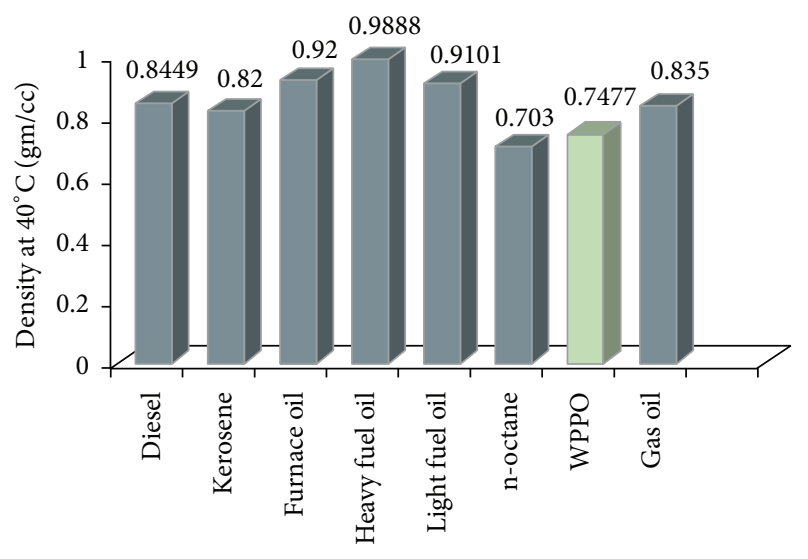

FIGURE 5: Graphical representation of density of different types of fuel.

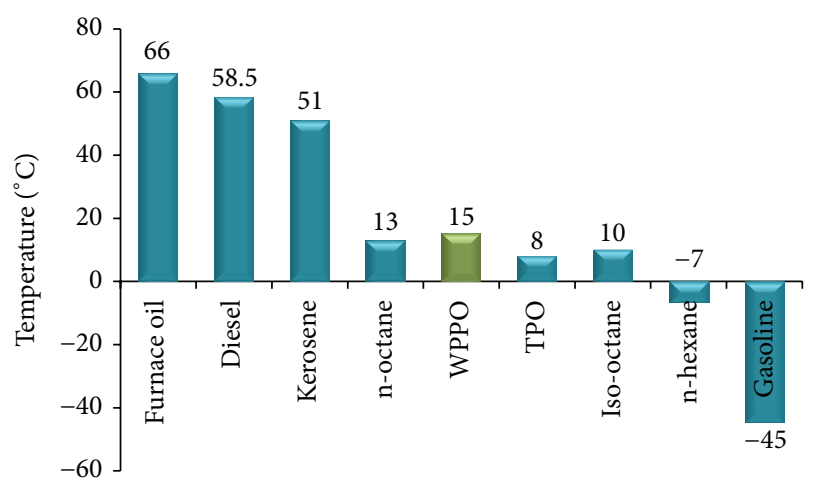

FIGURE 6: Graphical presentation of flash point of different oil.

from Figure 5 that the densities of WPPO and WPPO50 were found to be $0.7477 \mathrm{~g} / \mathrm{cc}$ and $0.7943 \mathrm{~g} / \mathrm{cc}$, respectively, which is close to the density of kerosene, diesel, and gas oil. So the conventional fuel such as diesel oil, kerosene oil, and gas oil may be replaced by plastic pyrolysis oil.

3.2.4. Flash Point. Flash point is the lowest temperature at which it can vaporize to form an ignitable mixture in air. Flash point is used to characterize the fire hazards of fuels. The flash point of WPPO was measured according to ASTM D 93-62 method. The flash point of WPPO was about $15^{\circ} \mathrm{C}$. A low flash point indicates the presence of highly volatile materials in the fuel that is a serious safety concern in handling and transporting. The flash point of furnace oil, diesel, and kerosene is higher than WPPO (Figure 6) which indicates that these are easy to handle. By removing lighter components (such as naphtha/gasoline) the flash point of WPPO will be increased.

3.2.5. Fire Point and Pour Point. The fire point of a fuel is the temperature at which it will continue to burn for at least 5 seconds after ignition by an open flame. The fire point is used to assess the risk of the materials ability to support combustion. Generally, the fire point of any liquid oil is

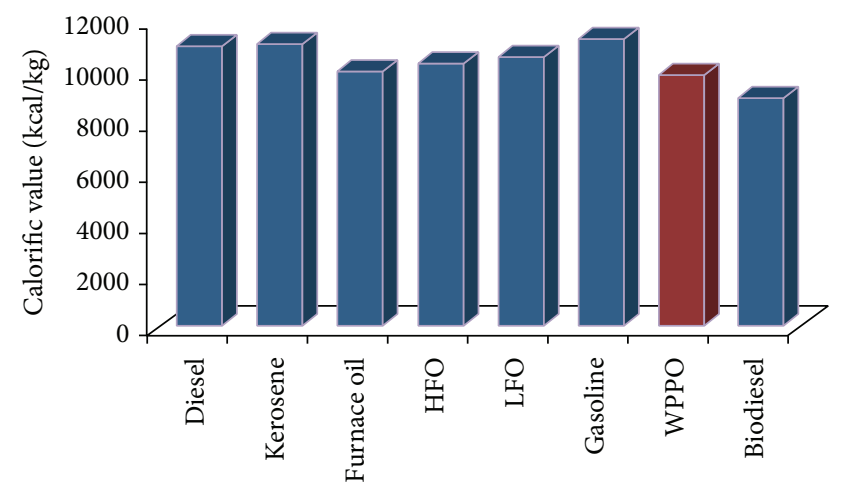

Figure 7: Comparison chart of calorific value of oil.

considered to be about $(5-10){ }^{\circ} \mathrm{C}$ higher than the flash point. The fire point of waste plastic pyrolysis oil was $20^{\circ} \mathrm{C}$.

The pour point is the temperature at which the oil will just ceases to flow when cooled at a standard rate in a standard apparatus. Pour point determines the suitability of oil for low temperature installations. The pour point of WPPO was measured by using ASTM D 97-57 methodology. The pour point was $<-15^{\circ} \mathrm{C}$. The low pour point value of WPPO indicates that it is not suitable in cold weather country.

3.2.6. Calorific Value. One of the important properties of a fuel on which its efficiency is judged is its calorific value. The calorific value is defined as the energy given out when unit mass of fuel is burned completely in sufficient air. The calorific value of WPPO was estimated according to IP 12/58 method. The calorific value of WPPO was $9829.3515 \mathrm{kcal} / \mathrm{kg}$. Figure 7 represents the comparison of calorific value of WPPO with other kinds of oil.

3.2.7. Sulphur and Ash Content. The presence of sulphur in vehicle fuels causes $\mathrm{SO}_{x}$ emissions that are an environmental issue. High sulphur content decreases the catalytic conversion capacity of a system, thus increasing the emissions of nitrous oxides $\left(\mathrm{NO}_{x}\right)$, carbon monoxide $(\mathrm{CO})$, hydrocarbons, and volatile organic compounds (VOCs). The sulphur content of WPPO was measured by using ASTM D 129-00 methodology.

The sulphur content of waste plastic pyrolysis oil was $0.246 \%$. Sulphur content of WPPO is slightly higher than gasoline $(0.014 \%)$, diesel $(0.15 \%)$, and other types of fuel oil because waste plastic contains some contamination (Figure 8).

The ash content of oil is the noncombustible residue. The ash content of distilled tire pyrolysis oil (DTPO) and DTPO50 (50\% DTPO : $50 \%$ diesel) was measured by using IP 04/58 test methodology. From Figure 9 it is clear that the ash content of WPPO was $0.0036 \%$ comparatively higher than diesel, light fuel oil, and kerosene. So it can be used as an alternative of furnace oil and heavy fuel oil (HFO).

3.2.8. Carbon Residue. Carbon residue indicates the tendency of oil to deposit a carbonaceous solid residue on a hot surface, such as a burner or injection nozzle, when its 


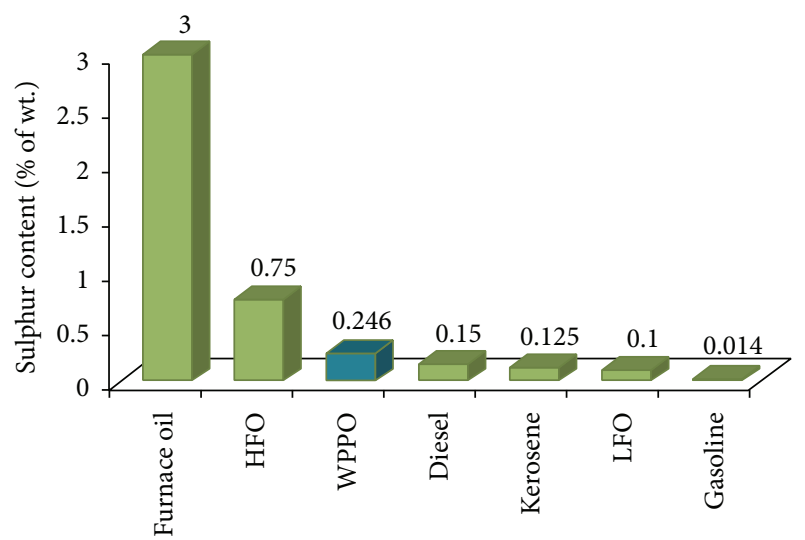

Figure 8: Sulphur content of different types of fuel oil.

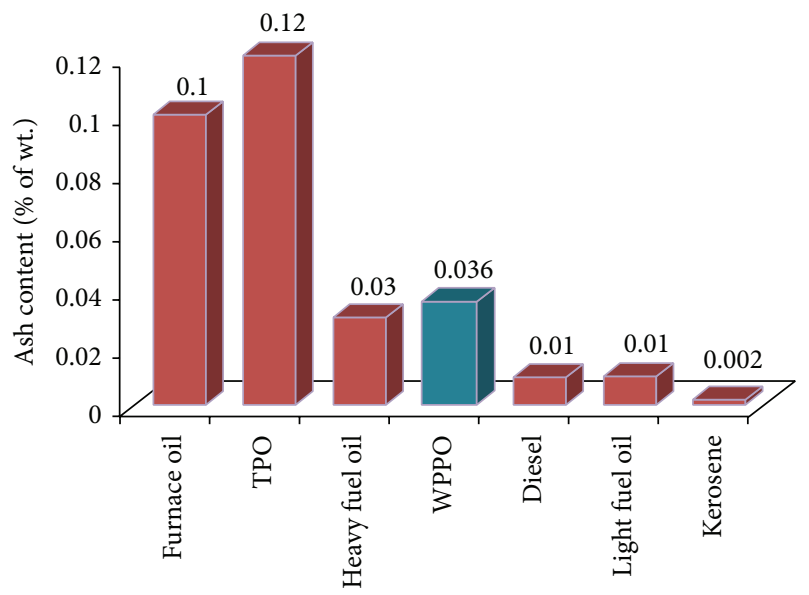

Figure 9: Ash content of different types of fuel oil.

vaporizable constituents evaporate. The carbon residue of WPPO was measured according to ASTM D 189-65 method. Oil which deposits minimum amount of carbon is naturally preferable.

Figure 10 shows that the carbon residue of the plastic pyrolysis oil was $0.5 \%$. In another study, $0.05 \%$ of carbon residue was reported [22]. The carbon residue of the diesel fuel and light fuel oil was comparatively higher than WPPO. This indicates that diesel fuels will form higher deposits. Fuels with high carbon residue content could cause increased fouling of the gas ways; more frequent cleaning is necessary, especially of the turbocharger and exhaust gas boiler.

\section{Conclusion}

The thermal pyrolysis of mixed plastic leads to the production of fuel oil which is a valuable resource recovery. It also reduces the problem of disposal of waste plastic. In this work, thermal pyrolysis of waste plastic is carried out because use of catalyst is costly and regeneration of catalyst is a difficult task. Mixed plastic pyrolysis yields a mixture of oil and gas and produces very small amount of char. Higher pyrolysis temperature and longer reaction times increase the gas yield and decrease

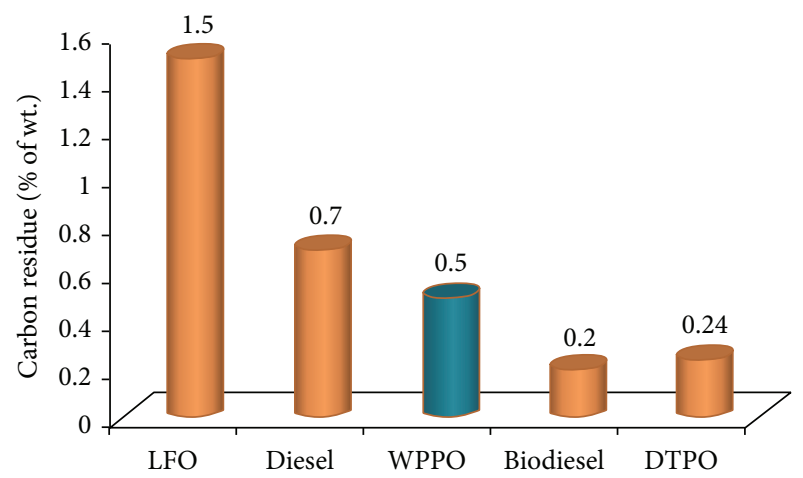

Figure 10: Carbon residue of different types of fuel oil.

char production. Highly volatile products are obtained at low temperature. Liquid yield increases as the holding time increases from $1 \mathrm{hr}$ to $2 \mathrm{hr}$, but as the holding time increases from $2 \mathrm{hr}$ to $3 \mathrm{hr}$, the liquid yield decreases. The maximum oil yield was $77.03 \%$ at $2 \mathrm{hr}$. The liquid obtained in this process is relatively greater volume and low boiling range. Distillation of fuel-like liquids shows more light fractions at higher temperature and longer time. Physicochemical properties of obtained fuel oil can be exploited to make highly efficient fuel or furnace oil after blending with other petroleum products. However, further studies are necessary to utilize this oil as fuel or feedstock.

\section{Competing Interests}

The authors declare that there are no competing interests.

\section{References}

[1] Z. Xiangxue, A. Jie, W. Yuzhong et al., "Progress of producing vehicle fuels from cracking waste plastics," Chemical Industry and Engineering Progress, vol. 31, pp. 389-401, 2012.

[2] L. Guangyu, L. Jian, M. Xiaobo et al., "Pyrolysis of MSW plastics: technologies and their reactors," Environmental Engineering, vol. 27, pp. 383-388, 2009.

[3] D.-M. Zheng, Q.-F. Lu, M. Liu, and Y.-X. Chen, "Study on the catalytic cracking of waste plastics and waste lubricating oil for producing fuel oil," Modern Chemical Industry, vol. 31, no. 8, pp. 47-49, 2011.

[4] D. Yafeng, H. Xiuling, W. Zhiwei et al., "The research and design of a new type of waste plastic cracking reactor," Machinery Design \& Manufacture, no. 1, pp. 20-22, 2013.

[5] W. Chao, M. Xiaobo, W. Hai et al., "Study on effective thermal conductivity coefficient of plastic wastes pyrolysis process," Materials Review, vol. 27, no. 5, pp. 108-111, 2013.

[6] Y.-B. Liu, X.-B. Ma, D.-Z. Chen, L. Zhao, and G.-M. Zhou, "Copyrolysis characteristics and kinetic analysis of typical constituents of plastic wastes," Proceedings of the Chinese Society of Electrical Engineering, vol. 30, no. 23, pp. 56-61, 2010.

[7] D. S. Achilias, C. Roupakias, P. Megalokonomos, A. A. Lappas, and E. V. Antonakou, "Chemical recycling of plastic wastes made from polyethylene (LDPE and HDPE) and polypropylene (PP)," Journal of Hazardous Materials, vol. 149, no. 3, pp. 536542, 2007. 
[8] M. L. Mastellone and U. Arena, "Bed defluidisation during the fluidised bed pyrolysis of plastic waste mixtures," Polymer Degradation and Stability, vol. 85, no. 3, pp. 1051-1058, 2004.

[9] M. Sarker, M. M. Rashid, R. Rahman, and M. Molla, "Conversion of low density polyethylene (LDPE) and polypropylene (PP) waste plastics into liquid fuel using thermal tracking process," British Journal of Environment \& Climate Change, vol. 2, no. 1, pp. 1-11, 2012.

[10] E. A. Williams and P. T. Williams, "Analysis of products derived from the fast pyrolysis of plastic waste," Journal of Analytical and Applied Pyrolysis, vol. 40-41, pp. 347-363, 1997.

[11] P. T. Williams and E. A. Williams, "Fluidised bed pyrolysis of low density polyethylene to produce petrochemical feedstock," Journal of Analytical and Applied Pyrolysis, vol. 51, no. 1, pp. 107126, 1999.

[12] K.-H. Lee, "Thermal degradation of heavy pyrolytic oil in a batch and continuous reaction system," Journal of Analytical and Applied Pyrolysis, vol. 86, no. 2, pp. 348-353, 2009.

[13] W. Kaminsky, M. Predel, and A. Sadiki, "Feedstock recycling of polymers by pyrolysis in a fluidised bed," Polymer Degradation and Stability, vol. 85, no. 3, pp. 1045-1050, 2004.

[14] H. Schmidt and W. Kaminsky, "Pyrolysis of oil sludge in a fluidised bed reactor," Chemosphere, vol. 45, no. 3, pp. 285-290, 2001.

[15] F. Pinto, P. Costa, I. Gulyurtlu, and I. Cabrita, "Pyrolysis of plastic wastes. 1. Effect of plastic waste composition on product yield," Journal of Analytical and Applied Pyrolysis, vol. 51, no. 1, pp. 39-55, 1999.

[16] D. S. Scott, S. R. Czernik, J. Piskorz, and D. S. A. G. Radlein, "Fast pyrolysis of plastic wastes," Energy \& Fuels, vol. 4, no. 4, pp. 407-411, 1990.

[17] H.-T. Lin, M.-S. Huang, J.-W. Luo, L.-H. Lin, C.-M. Lee, and K.-L. Ou, "Hydrocarbon fuels produced by catalytic pyrolysis of hospital plastic wastes in a fluidizing cracking process," Fuel Processing Technology, vol. 91, no. 11, pp. 1355-1363, 2010.

[18] W. L. Yoon, J. S. Park, H. Jung, H. T. Lee, and D. K. Lee, "Optimization of pyrolytic coprocessing of waste plastics and waste motor oil into fuel oils using statistical pentagonal experimental design," Fuel, vol. 78, no. 7, pp. 809-813, 1999.

[19] Y. Kodera, Y. Ishihara, and T. Kuroki, "Novel process for recycling waste plastics to fuel gas using a moving-bed reactor," Energy \& Fuels, vol. 20, no. 1, pp. 155-158, 2006.

[20] A. A. Garforth, Y.-H. Lin, P. N. Sharratt, and J. Dwyer, "Production of hydrocarbons by catalytic degradation of high density polyethylene in a laboratory fluidised-bed reactor," Applied Catalysis A: General, vol. 169, no. 2, pp. 331-342, 1998.

[21] G. Elordi, M. Olazar, G. Lopez et al., "Catalytic pyrolysis of HDPE in continuous mode over zeolite catalysts in a conical spouted bed reactor," Journal of Analytical and Applied Pyrolysis, vol. 85, no. 1-2, pp. 345-351, 2009.

[22] S. B. Desai, "Production and analysis of pyrolysis oil from waste plastic in Kolhapur city," International Journal of Engineering Research and General Science, vol. 3, no. 1, pp. 590-595, 2015. 


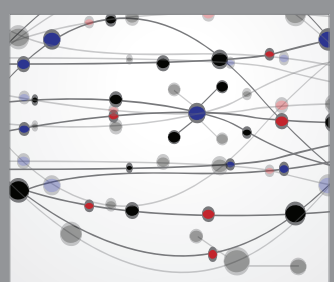

The Scientific World Journal
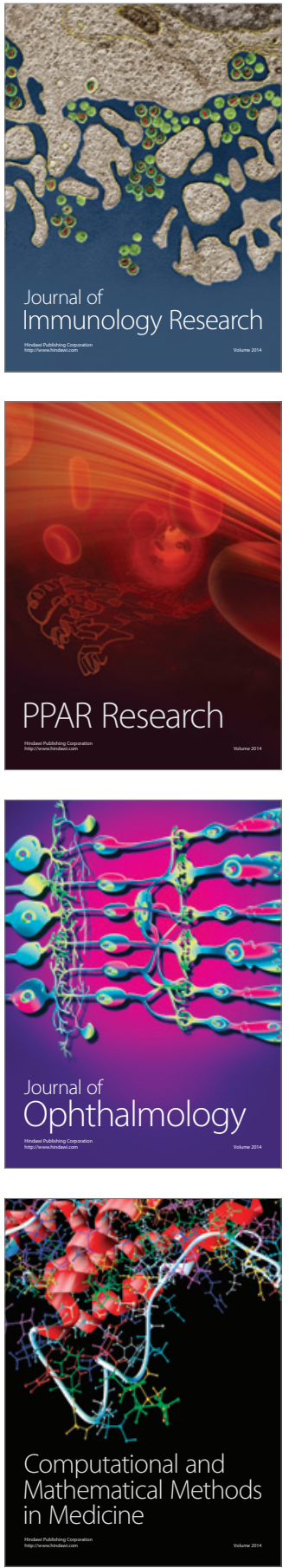

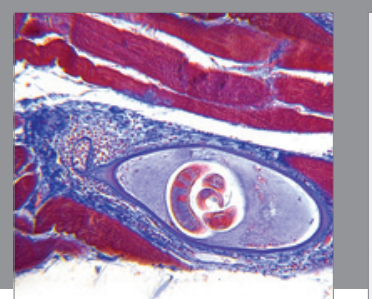

Gastroenterology Research and Practice

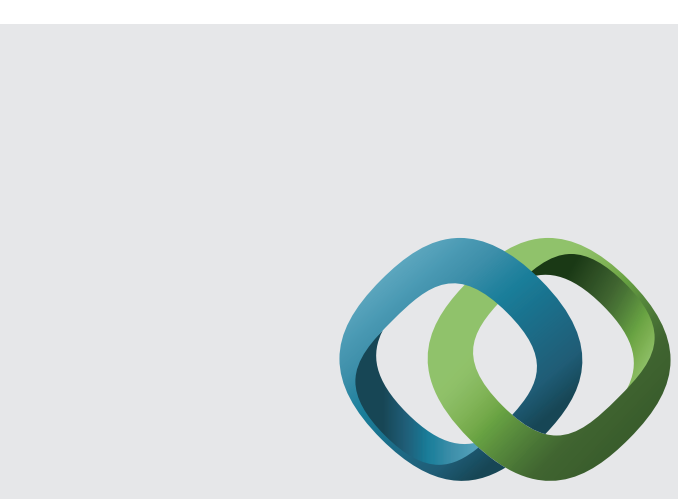

\section{Hindawi}

Submit your manuscripts at

http://www.hindawi.com
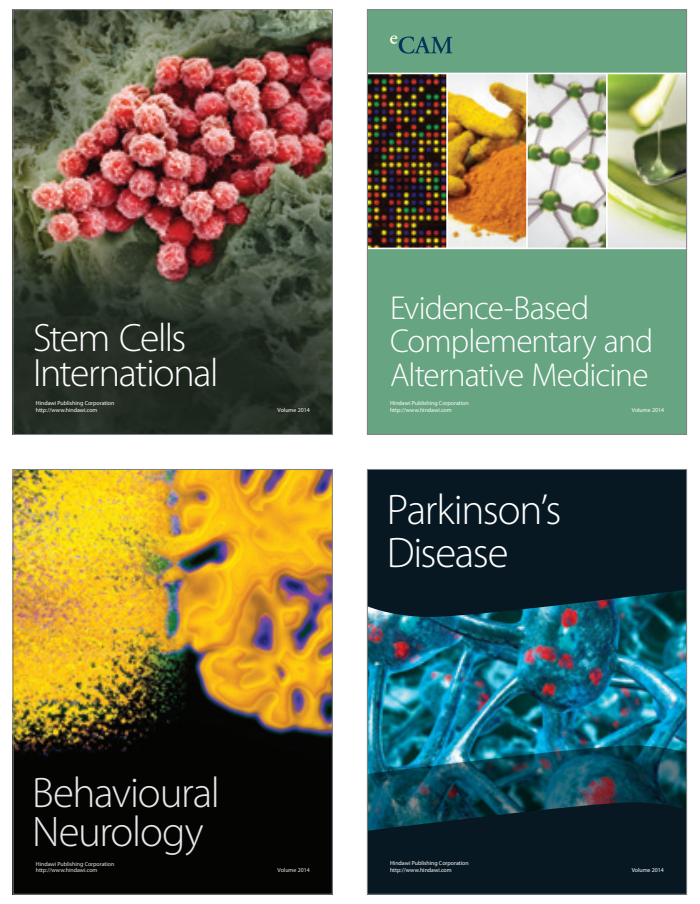
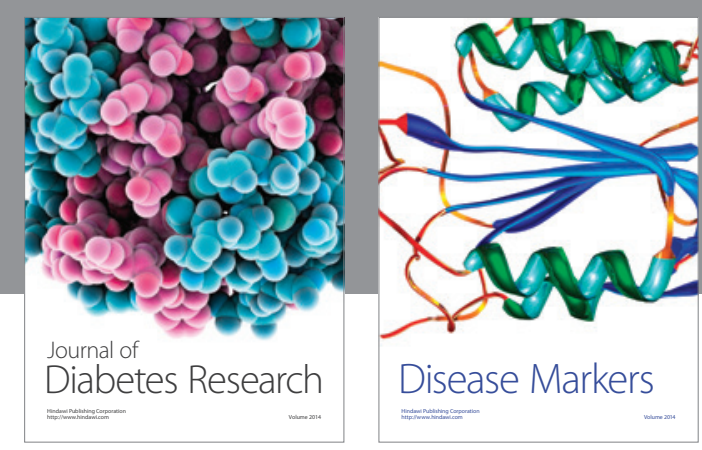

Disease Markers
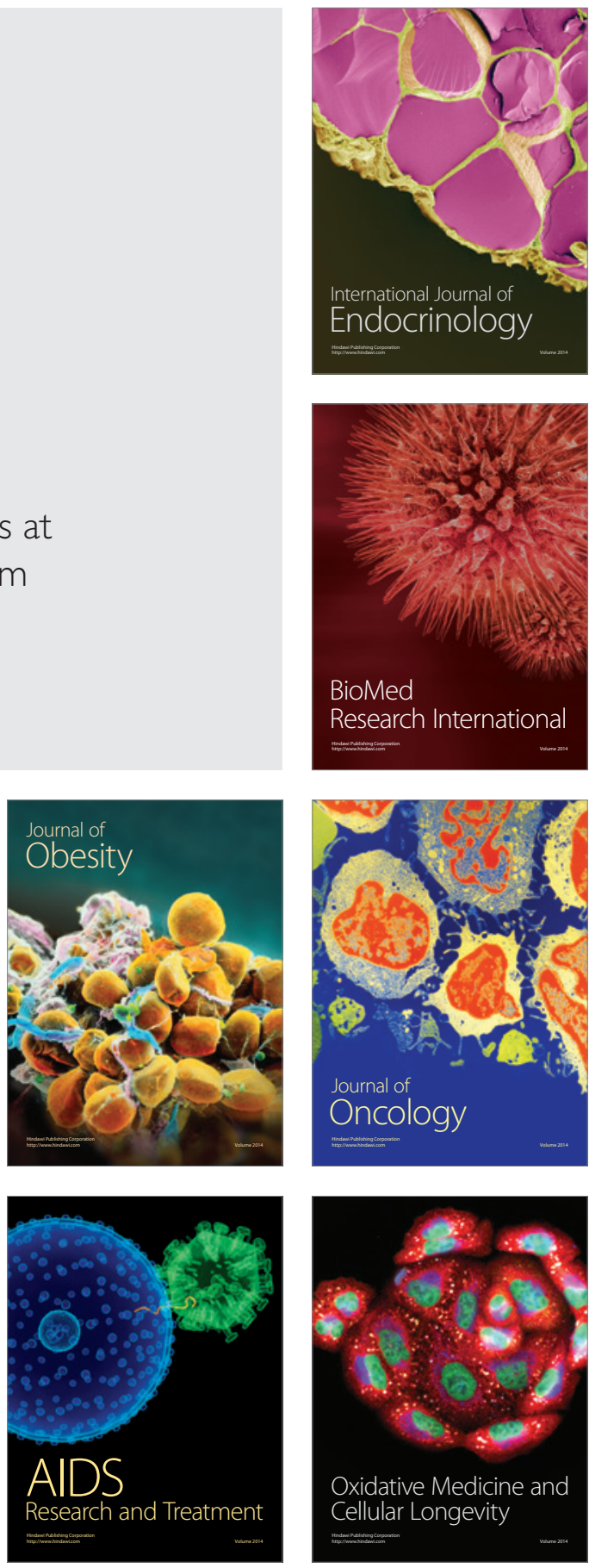